Extrait du Journal de la Socièté des Américanisles de Paris,

Nouvelle série, tome III, numéro 1.

\title{
SOPHUS RUGE
}

\section{ET SES VUES SUR GOLOMB}

\author{
PAR \\ M. Henry VignaUd \\ VICE-PRÉSIDENT DE LA SOCIÉTÉ DES AMÉRICANISTES
}

$\frac{c c a p n s}{\text { ccamp }}$

AU SIĖGE DE LA SOCIÉTÉ

61 , RUE DE BUFFon, 61

1906 